\title{
Correction: Bronisz K. and Zasada M., Comparison of Fixed- and Mixed-Effects Approaches to Taper Modeling for Scots Pine in West Poland. Forests 2019, 10,975
}

\author{
Karol Bronisz * and Michał Zasada \\ Institute of Forest Sciences, Warsaw University of Life Sciences-SGGW, Nowoursynowska 159, \\ PL 02-776 Warsaw, Poland; michal.zasada@wl.sggw.pl \\ * Correspondence: karol.bronisz@wl.sggw.pl
}

Received: 12 April 2020; Accepted: 12 April 2020; Published: 13 April 2020

check for updates

After publication of the research paper [1], the authors wish to make the following correction. The correction concerns the placement of information that the article was also financed by the Polish National Agency for Academic Exchange as part of the Foreign Promotion Program. Placing this information allows to participate in the above Promotion Program and obtaining support in financing the publication of the article.

The authors would like to apologize for any inconvenience caused. The change does not affect the scientific results. The manuscript will be updated and the original will remain online on the article webpage, with a reference to this correction.

Funding: The research was financed by (i) the Ministry of Science and Higher Education research grant "Assessment of the carbon accumulation in Scots pine complexes of western Poland and determination of the influence of various silvicultural alternatives on carbon sequestration dynamics", (ii) the General Directorate of State Forests research grant: "Ecological and economic consequences of the selected alien tree species silviculture in Poland", (iii) Warsaw University of Life Sciences-SGGW scholarship fund, and (iv) Polish National Agency for Academic Exchange as part of the Foreign Promotion Program.

\section{Reference}

1. Bronisz, K.; Zasada, M. Comparison of Fixed- and Mixed-Effects Approaches to Taper Modeling for Scots Pine in West Poland. Forests 2019, 10, 975.

(C) 2020 by the authors. Licensee MDPI, Basel, Switzerland. This article is an open access article distributed under the terms and conditions of the Creative Commons Attribution (CC BY) license (http://creativecommons.org/licenses/by/4.0/). 